\title{
SISTEMATIK RISK, PERSISTENSI LABA TERHADAP EARNINGS RESPONSE COEFFICIENT PADA ENTITAS INDUSTRI
}

\author{
Lalu Takdir Jumaidi ${ }^{1}$, Rijal $^{2}$ \\ 1Program Magister Manajemen, Universitas Mataram, Indonesia. \\ Email : takdirjumaidi@yahoo.com
}

\begin{tabular}{|c|c|}
\hline ARTICLE INFO & ABSTRACT \\
\hline $\begin{array}{l}\text { Keywords : } \\
\text { systematic risk, earnings persistence, } \\
\text { earnings response coefficient } \\
\text { How to cite: } \\
\text { Jumaidi,Lalu Takdir., Rijal (2018). } \\
\text { Leverage, Persistensi Laba dan Sistematik } \\
\text { Risk, Terhadap Earnings Response } \\
\text { Coefficient } \\
\text { Pada Entitas Industri. JMM UNRAM, } \\
7(2), 1 \text { - } 16 \\
\text { DOI : } \\
\text { 10.29303/jmm.v7i2.286 }\end{array}$ & $\begin{array}{l}\text { Investors use financial statement information in their } \\
\text { investment decisions. Earnings is usually the main } \\
\text { consideration of investors in making decision. However, the } \\
\text { increase in earnings is not always followed by positive stock } \\
\text { price changes. It shows that in economic decision-making the } \\
\text { investors not only need information about the company's } \\
\text { financial condition, i.e profit, but also other information. } \\
\text { Therefore, investors need useful tool to predict the up or rise of } \\
\text { stock price namely earnings response coefficient which shows } \\
\text { market reaction on earnings information published by } \\
\text { company. If the investor perceived the information content of } \\
\text { the announced profits as good quality then the investors will } \\
\text { react positively to earnings anouncement. } \\
\text { Therefore purpose of this study is to examine the effect of } \\
\text { systematic risk, and earnings persistence on earnings } \\
\text { response coefficient at manufacturing companies listed on the } \\
\text { Stock Exchange. The population in this study are all } \\
\text { manufacturing companies listed on the IDX in 2015. This } \\
\text { study is determined by the method of purposive sampling and } \\
\text { this study obtained 56 sample companies. The study } \\
\text { usesecondary data which is obtained from www.idx.co.id. The } \\
\text { results of this study based on multiple regression analysis } \\
\text { indicate that systematic risk, leverage and profit persistence } \\
\text { have no effect on earnings response coefficient. } \\
\text { Para Investor dalam pengambilan keputusan } \\
\text { investasinya, menggunakan informasi laporan keuangan. } \\
\text { Laba biasanya menjadi pertimbangan utama investor. } \\
\text { Namun kenaikan laba tidak selalu diikuti dengan perubahan } \\
\text { harga saham yang positif. Hal tersebut menunjukkan, dalam } \\
\text { pengambilan keputusan ekonomi, para investor membutuhkan } \\
\text { informasi tentang kondisi keuangan perusahaan tidak hanya }\end{array}$ \\
\hline
\end{tabular}




\section{PENDAHULUAN}

Risiko sistematik atau disebut juga reaksi investor terhadap risiko pasar (market risk). Risiko sistematik merupakan inherent risk yaitu risiko yang tidak dapat dihilangkan melalui diversifikasi dalam portofolio. Risiko ini tidak dapat dihilangkan dengan diversifikasi karena risiko sistematik dipengaruhi oleh faktor-faktor makro yang mempengaruhi pasar, misalnya perubahan tingkat bunga, kurs valuta asing, kebijakan pemerintah, resesi ekonomi dan sebagainya (Halim,2005). Risiko sisitematik diukur denga beta. Beta sama dengan satu menunjukkan bahwa harga saham bergerak mengikuti pergerakan pasar. Semakin peka perubahan harga saham maka semakin tinggi nilai beta. Semakin tinggi nilai beta maka semakin tinggi pula risiko sistematik suatu perusahaan (Brigham dan Houston (2001)

Perusahaan dengan risiko sistematik yang rendah, ketika laba diumumkan maka investor akan bereaksi positif terhadap saham perusahaan tersebut sehingga Earnings Response Coefficient (ERC) perusahaan tersebut tinggi begitupun sebaliknya jika risikonya tinggi maka Earnings Response Coefficient akan rendah.

Persistensi laba mencerminkan kualitas laba perusahaan dan menunjukkan bahwa perusahaan dapat mempertahankan laba dari waktu ke waktu dan bukan hanya karena suatu peristiwa tertentu. Scott (2009) mengatakan bahwa semakin tinggi perubahan laba, maka semakin tinggi pula Earnings Response Coefficient(ERC). Hal tersebut menunjukkan bahwa laba yang diperoleh perusahaan dapat meningkat secara terus menerus ataupun stabil dimasa yang akan datang. Romasari (2013) juga meneliti dengan hasil penelitian bahwa persistensi laba, struktur modal tidak berpengaruh signifikan negatif terhadap kualitas laba sedangkan ukuran 
perusahaan tidak berpengaruh positif terhadap kualitas laba perusahaan manufaktur yang terdaftar di Bursa Efek Indonesia(BEI). Penelitian Lukman (2014) menunjukkan bahwa ukuran perusahaan dan kesempatan bertumbuh tidak memiliki pengaruh terhadap koresponan laba

Motivasi dilakukan penelitian mengenai kualitas laba adalah karena informasi laba merupakan informasi penting bagi investor dalam mengambil keputusan terkait dengan investasi yang akan dilakukan sehingga kualitas dari informasi laba yang dilaporkan perusahaan menjadi perhatian utama karena kualitas informasi laba yang rendah akan menyesatkan investor dalam pengambilan keputusan. Berdasarkan latar belakang di atas, peneliti tertarik untuk melakukan penelitian dengan judul "Sistematik Risk dan Persistensi Laba Terhadap Earnings Response Coefficient Pada Perusahaan Manufaktur".

\section{TINJAUAN PUSTAKA}

\subsection{Tinjauan Teoritis}

2.1.1. Teori Sinyal (Signalling Theory)

Signalling Theory pertama kali dikemukakan oleh Spence tahun 1973yang menunjukkan adanya asimetri informasi antara pihak manajemen perusahaan dan berbagai pihak yang berkepentingan, berkaitan dengan informasi yang dikeluarkan tersebut (Santoso, 2015). Asimetri informasi adalah ketidaksamaan informasi yang didapat antara manajemen perusahaan dengan pemegang saham perusahaan (Paramita, 2012). Jama'an dalam Gogo (2015) melalui signaling theory mengemukakan tentang bagaimana seharusnya pihak manajemenperusahaan memberikan sinyal kepada pengguna laporan keuangan. Teori sinyal menekankan kepada pentingnya informasi yang dipublikasikan oleh perusahaan terhadap keputusan investasi pihak di luar perusahaan.

\subsubsection{Earnings Response Coefficient (ERC)}

Kartajumena (2010), menyata kan kuatnya reaksi pasar terhadap informasi laba akan tercermin dari tingginya Earnings Response Coefficient (ERC), sebaliknya lemahnya reaksi pasar terhadap informasi laba akan tercermin nilai ERC yang rendah.

Dasar pemikiran ERC adalah bahwa investor memiliki perhitungan ekspektasi laba jauh hari sebelum laporan keuangan dikeluarkan. Periode peramalan laba dapat mencapai satu tahun sebelum diumumkannya angka laba perusahaan. Menjelang dikeluarkannya laporan keuangan, investor akan lebih memiliki banyak informasi dalam membuat analisis terhadap angka laba periodik. Hal ini dapat terjadi karena seringnya terdapat kebocoran informasi menjelang dikeluarkannya laporan keuangan (Sri, 2008).

\subsubsection{Risiko Sistematik}

Risiko sistematik merupakan besarnya penyimpangan antara expected return dengan actual return. Semakin besar penyimpangan berarti semakin besar tingkat resiko investasi tersebut (Halim, 2005) dalam Delvira (2013).

\subsubsection{Persistensi Laba}

Persistensi laba merupakan suatu ukuran yang menjelaskan kemampuan perusahaan untuk mempertahankan jumlah laba yang diperoleh saat ini sampai masa mendatang. Persistensi laba sering digunakan sebagai pertimbangan kualitas laba karena persistensi laba 


\section{NATIONALLY ACCREDITED JOURNAL - DECREE NO.21/E/KPT/2018}

merupakan komponen dari karakteristik kualitatif relevansi yaitu predictive value (Mulyani, 2011).

\subsection{Kerangka Konseptual}

Penelitian ini meneliti pengaruh risiko, leverage dan persistensi laba terhadap earning response coefficient. Model penelitian tersebut menggambarkan suatu kerangka konseptual sebagai panduan sekaligus alur berpikir, serta sebagai dasar perumusan hipotesis yang ditunjukkan dalam gambar berikut:

Gambar 2.1

\section{Kerangka Konseptual}

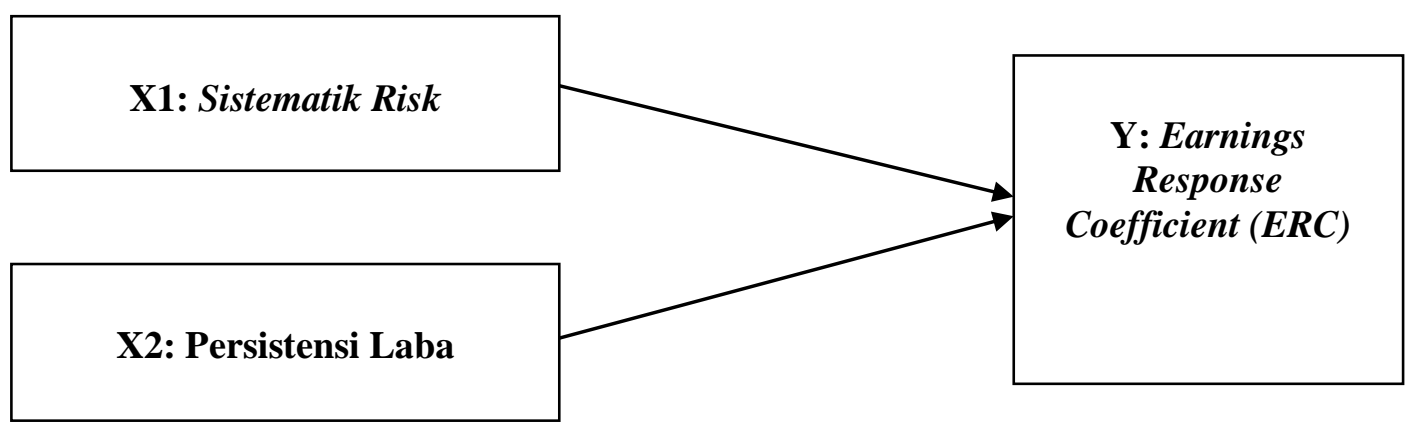

\subsection{Pengembangan Hipotesis}

2.3.1. Hubungan Risiko Sistematik dengan Earnings Response Coefficient (ERC)

Penelitian Delvira dan Nelvirita (2013), bahwa risiko Sistematik berpengaruh negatif terhadap earnings response coefficient (ERC). Semakin peka return saham terhadap return pasar, semakin tinggi pula resiko sistematiknya.Resiko ini dipengaruhi oleh faktor eksternal perusahaan. Meskipun operasional perusahaan berjalan dengan baik dan harga saham tidak ada alasan untuk turun, namun tetap saja pasar bereaksi negatif akibat munculnya resiko pasar. Semakin berfluktuasi perubahan saham akibat kondisi pasar (menyebabkan beta tinggi), pendapatan yang akan diterima investor pada akhir periode akan sulit diprediksi. Penelitian ini juga didukung dengan penelitian yang telah dilakukan oleh Sri dan Nur (2007) yang menemukan bahwa resiko sistematik atau beta berpengaruh signifikan negatif terhadap earnings response coefficient (ERC).

\section{$\mathrm{H}_{1}$ : Resiko sistematik berpengaruh terhadap Earnings Response Coefficient}

\subsubsection{Hubungan persistensi laba dengan Earnings Response Coefficient}

Menurut Scott (2009) Persistensi laba adalah revisi laba yang diharapkan dimasa mendatang (expected future earnings) yang diimplikasikan oleh inovasi laba tahun berjalan sehingga persistensi laba dapat dilihat dari inovasi laba tahun berjalan yang dihubungkan dengan perubahan harga saham.

$\mathrm{H}_{2}$ : Persistensi laba berpengaruh terhadap Earnings Response Coefficient 


\section{METODE PENELITIAN}

\subsection{Jenis Penelitian}

Jenis penelitian yang digunakan dalam penelitian ini adalah hubungan kausal. Hubungan kausal adalah hubungan yang bersifat sebab akibat dimana ada variabel independen (variabel yang mempengaruhi) dan variabel dependen (variabel yang dipengaruhi).

\subsection{Lokasi dan Waktu Penelitian}

Penelitian ini dilakukan pada perusahaan manufaktur yang terdaftar di Bursa Efek Indonesia tahun 2015 yang diperoleh dari website resmi BEI yaitu www.idx.co.id.

\subsection{Populasi dan Sampel}

\subsubsection{Populasi}

Dalam penelitian ini ditentukan bahwa yang menjadi populasi adalah semua perusahaan manufaktur yang terdaftar di Bursa Efek Indonesia pada tahun 2015. Berdasarkan data yang diperoleh, terdapat 144 perusahaan manufaktur yang terdaftar di Bursa Efek Indonesia.

\subsubsection{Sampel}

Jenis metode pemilihan sampel yang digunakan dalam penelitian ini adalah purposive sampling. Berdasarkan kriteria yang telah dipaparkan di atas, diperoleh sampel sebanyak 56 perusahaan.

\subsection{Variabel Penelitian}

\subsubsection{Definisi Operasional Variabel}

\subsubsection{Risiko Sistematik}

Beta $(\beta)$ suatu sekuritas mampu menunjukan risiko sistematik yang tidakdapat dihilangkan karena diversifikasi. Investor harus mampu menghitung risiko sistematik dari suatu investasi untuk menentukan investasi yang terbaik. Untuk menghitung besarnya risiko, metode yang diguna kan adalah menghitung varians dan standar deviasi yang mengukur penyimpangan nilai yang terjadi dengan nilai return yang diharapkan. Menurut (Suad, 2008) beta digunakan untuk mengukursensitifitas dari individual saham terhadap resiko pasar. Kontribusi dari suatu saham terhadap resiko dari suatu portofolio tergantung dari bagaimana saham tersebut dipengaruhi oleh pergerakan pasar.

Koefisien beta diperoleh dari regresi antara return saham dengan return pasar, yakni dengan rumus sebagai berikut (Suad, 2005):

$$
\mathrm{R}=\mathrm{\alpha}+\beta \mathrm{Rm}+\mathrm{e}
$$

Keterangan:

$\mathrm{R}=$ Return saham

$\beta=$ Beta saham (indikator risiko sistematis)

$\mathrm{Rm}=$ Return pasar

Menghitung return saham dan return pasar dapat ditentukan dengan rumus sebagai berikut: 
1. Menghitung Return saham

$$
\text { Rit }=\frac{(\text { pit }- \text { pit }-1)}{\text { Pit }-1}
$$

Dimana:

Rit $=$ Return saham perusahaan i pada hari ke $\mathrm{t}$

Pit $=$ Harga penutupan saham $\mathrm{i}$ pada hari ke $\mathrm{t}$

Pit-1 = Harga penutupan saham i pada hati ke $\mathrm{t}-1$

2. Menghitung return pasar harian :

$$
\mathrm{Rmt}=\frac{(I H S G t-I H S G t-1)}{I H S G t-1}
$$

Dimana:

Rmt $=$ Return pasar harian

IHSGt $=$ Indeks harga saham gabungan pada hari $t$

IHSGt-1 = Indeks harga saham gabungan pada hari t-1

\subsubsection{Persistensi Laba}

Definisi persistensi laba menurut Scott (2009) adalah revisi laba yang diharapkan dimasa mendatang (expected future earnings) yang diimplikasikan oleh inovasi laba tahun berjalan sehingga persistensi laba dilihat dari inovasi laba tahun berjalan yang dihubungkan dengan perubahan harga saham. Besarnya revisi ini menunjukan tingkat persistensi laba. Inovasi terhadap laba sekarang adalah informatif terhadap laba masa depan ekspektasian, yaitu manfaat masa depan yang diperoleh pemegang saham (Wijayanti, 2009). Persistensi laba dapat ditentukan dengan rumus sebagai berikut:

Keterangan:

$$
\text { Xit }=\alpha+\beta \text { Xit }-1+\varepsilon 1
$$

$$
\begin{aligned}
& \text { Xit }=\text { Laba perusahaan i pada tahun } \mathrm{t} \\
& \text { Xit- } 1=\text { Laba perusahaan i pada tahun } \mathrm{t}-1 \\
& \beta=\text { Koefisien hasil regresi (persistensi laba) }
\end{aligned}
$$

\subsubsection{Earnings Response Coefficient}

Earning Response Coefficient merupakan reaksi CAR terhadap laba yangdiumumkan oleh perusahaan (Darwanis dan Andina, 2013). ERC diperoleh dari regresi antara Cumulative Abnormal Return (CAR) dan Unexpected Earnings (UE). Dengan demikian, untuk menghitung besarnya ERC, harus dihitung terlebih dahulu nilai CAR dan UE masing-masing perusahaan. Cummulative AbnormalReturn (CAR) ialah penjumlahan return tak normal hari sebelumnya didalamperiode peristiwa untuk masing-masing sekuritas (Jogiyanto 2016:663). Return tak normal adalah selisih antara return sesungguhnya yang terjadi dengan return ekspektasian (Jogiyanto 2016:647).

Dengan demikian untuk menghitung earning response coefficient diperlukan beberapa langkah yaituMenghitung Cummulative Abnormal Return (CAR).Adapun langkah-langkah untuk menghitung CAR (Jogiyanto, 2016) yaitu: 
1. Menghitung abnormal

Keterangan:

ARit : Abnormal Return untuk perusahaan i pada periode ke $t$

Rit : Return perusahaan pada periode ke $t$

Rmt : Return pasar pada periode ke $\mathrm{t}$

2. Menghitung cumulative abnormal return untuk masing-masing

perusahaan

$$
C A R_{i(t-3, t+3)}=\sum_{t=-3}^{t=+3} A R_{i t}
$$

Keterangan:

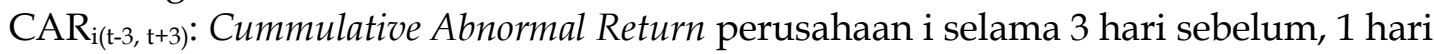
tanggal publikasi dan 3 hari sesudah labadipublikasi.

Arit: Abnormal Return untuk perusahaan i

UE atau unexpected earning ialah pengurangan antara laba sebenarnya dengan laba yang diharapkan (Fitri, 2013). UE dihitung dengan model sebagai berikut:

$$
U E_{i, t}=\frac{E_{i, t}-E_{i, t}-1}{P_{i, t}-1}
$$

Keterangan:

$\mathrm{UEi}, \mathrm{t} \quad$ : unexpected earning perusahaan i pada tahun $\mathrm{t}$

$\mathrm{Ei}, \mathrm{t} \quad$ : laba akuntansi setelah pajak perusahaan i pada tahun $\mathrm{t}$

E : laba akuntansi setelah pajak perusahaan i pada tahun sebelum ti,t-1

3. Menghitung Earning Response Coefficient

Earning response coefficient dihitung melalui persamaan regresi atas data setiap perusahaan (Fitri, 2013).

\subsection{Jenis dan Sumber Data}

\subsubsection{Jenis Data}

Jenis data yang digunakan dalam penelitian ini adalah data kuantitatif. Data kuantitatif yang digunakan dalam penelitian ini adalah laporan tahunan perusahaan manufaktur dari tahun 2013-2015 di Bursa Efek Indonesia .

\subsubsection{Sumber Data}

Data yang digunakan dalam penelitian ini data sekunder. Data sekunder dalam penelitian ini berupa laporan tahunan perusahaan manufaktur yang terdaftar di BEI yang diperoleh dari situs www.idx.co.id, IHSG serta harga saham harian perusahaan yang diperoleh melalui website www.yahoofinance.com.

\subsection{Teknik Pengumpulan Data}

Teknik pengumpulan data yang digunakan dalam penelitian ini yaitu dokumentasi. Teknik dokumentasi adalah teknik pengumpulan data dengan mendapatkan data laporan tahunan yang diterbitkan perusahaanperiode 2013-2015. 


\section{HASIL DAN PEMBAHASAN}

\subsection{Analisis Statistik Deskriptif}

Statistik deskriptif dalam penelitian ini digunakan untuk mendeskripsikan variabelvariabel seperti risiko sistematik, persistensi laba dan earnings response coefficient. Dengan analisis statistik deskriptif dapat diketahui nilai maksimum, minimum, mean dan standae deviasi dari ketiga variabel. Berikut hasil dari analisis statistik deskriptif dari variabel dalam penelitian ini.

Tabel 4.1

Hasil Statistik Deskriptif

\begin{tabular}{|l|l|l|l|l|l|}
\hline & $\mathrm{N}$ & Minimum & Maximum & Mean & Deviation \\
\hline RS & 56 & $-9,86$ & 6,54 &,- 2045 & 2,58854 \\
\hline ERC & 56 & $-1,44$ &, 44 &,- 0251 &, 24844 \\
\hline PL & 56 & $-3,05$ & 6,03 &, 1251 & 1,30036 \\
\hline Valid N & 56 & & & & \\
\hline (listwise) & & & & & \\
\hline
\end{tabular}

Sumber: Hasil SPSS, 2018

Berdasarkan tabel diatas, variabel risiko sistematik (RS) memiliki nilai rata-rata sebesar 0,2045, lebih kecil dari standar deviasi sebesar 2,58854. Nilai minimum sebesar $-9,86$ dimiliki oleh PT Gudang Garam tbk, sedangkan nilai maksimum dimiliki oleh PT Semen Indonesia Tbk Semen Gresik Tbk sebesar 6,54. Hasil ini menunjukkan adanya fluktuasi nilai beta selama periode penelitian.

Variabel earnings response coefficient (ERC) memiliki nilai rata-rata sebesar -,0251 menunjukkan bahwa rata-rata para investor memberikan respon yang cukup rendah terhadap pengumuman laba perusahaan yang tercermin dari rata-rata nilai ERC yang masih dibawah angka 1. Dengan kata lain, rata-rata ERC dari perusahaan sampel selama tahun pengamatan penelitian menunjukkan nilai yang cukup rendah. Nilai minimum -1,44 yang dimiliki oleh PT Pabrik Kertas Tbk dan nilai maksimum sebesar 0,44 yang dimiliki oleh PT Gudang Garam tbk. Standar deviasi sebesar 0,24844 menunjukkan besarnya batas penyimpangan data.

Variabel persistensi laba (PL) dengan nilai rata-rata 0,1251 yang menunjukkan bahwa kemampuan perusahaan untuk mempertahankan laba dari periode ke periode cukup baik (persisten), karena perusahaan dikatakan persisten jika memiliki nilai $(\beta 1)>0$. Nilai minimum sebesar -3,05 yang dimiliki oleh PT Ultrajaya Milk Industry and Trading Company Tbk, sedangkan nilai maksimum 6,03 yang dimiliki oleh PT. Astra Auto Part Tbk. Standar deviasi sebesar 1,30036. 


\subsection{Uji Asumsi Klasik}

\subsubsection{Uji normalitas}

Uji normalitas dalam pẹelitian ini menggunakạn pengujian statistik non parametrik Kolmogorov-Smirnov (KS) test. Pengambilan kesimpulan dalam pengujian ini dapat dilihat dari nilai signifikansinya atau Asymp. Sig (2-tailed). Dengan kriterian pengukuran tingkat signifikansi 5\% atau 0,050. Data dikatakan berdistribusi normal apabila Asymp. Sig (2-tailed) lebih besar dari 0,050 .

Dari table hasil Uji normalitas menyajikan hasil uji normalitas One-Sample KolmogrovSmirov(K-S). nilai Asymp. Sig (2-tailed) adalah 0,000 atau berada di bawah 0.05 sehingga dapat dikatakan bahwa data residual tidak berdistribusi normal. Hal ini karena terdapat data yang memiliki range terlalu tinggi atau rendah.

Menurut Ghozali (2016:41) data yang tidak berdistribsi normal dapat diatasi dengan cara outlier. Outlier adalah data yang terlihat sangat berbeda jauh dengan hasil observasi lainnya dan muncul dalam bentuk nilai ekstrim, data outlier dikeluarkan dari pengamatan. Adapun yang memiliki nilai Z-score dengan rentang -2,5 sampai dengan 2,5 cenderung menghasilkan normalitas yang lebih baik.Hasil pengujian normalitas setelah menggunakan outlier menunjukkan nilai Asymp. Sig (2-tailed) sebesar 0,200. Hal ini menunjukkan bahwa nilai signifikansi tersebut diartikan signifikan karena lebih besar dari 5\% atau 0,05. Berdasarkan hasil pengujian tersebut dapat ditarik kesimpulan bahwa data residual telah terdistribusi secara normal atau memenuhi asumsi klasik normalitas.

\subsubsection{Uji Multikolinearitas}

Uji multikolinearitas bertujuan untuk menguji apakah pada model regresi ditemukan adanya korelasi antar variabel bebas (independen). Hasil uji dikatakan baik adalah jika tidak terjadi multikoliearitas yaitu apabila nilai tolerance $>0,10$ dan VIF $<10$ maka tidak terjadi multikolinearitas yang artinya tidak ada korelasi antar variabel independen (Ghozali, 2016).

Berdasarkan hasiluji Multikolinearitas dapat dilihat nilai tolerance dari masing-masing variabel yakni $(0,949 ; 0,948)$ yang lebih besar dari 0,10 dan nilai VIF dari masing-masing varibale yakni $(1,054 ; 1,075 ; 1,055)$ yang lebih kecil dari10 yang berarti bahwa tidak ada korelasi antar variabel independen, sehinggadapat disimpulkan bahwa model regresi tidak mengalami masalah multikolinieritas, sehingga dapat dikatakan bahwa model regresi yang digunakan baik karena tidak terjadi korelasi diantara variabel independen tersebut.

\subsubsection{Uji Heteroskedastisitas}

Uji heteroskedatisitas bertujuan untuk mengetahui ada tidaknya heteroskedastisitas. Pengujian heteroskedastisitas dalam penelitian ini menggunakan Uji Glejser dengan tingkat signifikansi 5\%. Berikut hasil pengujian heteroskedastisitas dari masing-masing variabel:

Berdasarkan pengujian menunjukkan bahwa tingkat signifikansi dari variabel independen yakni $(0,523 ; 0,093 ; 0,285)$ lebih besar dari nilai alpha $(0,050)$. Hal ini menunjukkan model regresi terbebas dari masalah heteroskedastisitas.

\subsubsection{Uji Autokorelasi}

Pengujian autokorelasi dalam penelitian ini dilakukan dengan menggunakan uji Durbin-Watson. Berikut adalah hasil pengujian autokorelasi: 


\section{NATIONALLY ACCREDITED JOURNAL - DECREE NO. 21/E/KPT/2018}

Tabel.4.2 Uji Autokorelasi

\begin{tabular}{|l|l|l|l|l|l|}
\hline \multirow{2}{*}{ Model } & $\mathrm{R}$ & $\mathrm{R}$ & Adjusted & Std. & \\
& & Square & $\mathrm{R}$ & Error of & Durbin- \\
& & Square & the & Watson \\
\hline 1 &, $297 \mathrm{a}$ &, 088 &, 026 &, 11416 & 1,665 \\
\hline
\end{tabular}

Berdasarkan tabel 4.2 di atas dapat dilihat bahwa nilai Durbin-Watson (DW) sebesar 1,665. Hasil nilai DW tersebut dapat dibandingkan dengan tabel Durbin-Watson d Statistic: Significance point for $d l$ and $d u$ at 0,05 level ofsignificance dalam mengambil sebuah keputusan hasil autokorelasi. Terkaitdengan tabel tersebut, jumlah sampel yang digunakan $48(\mathrm{n}=48)$ dan jumlah variabel independen $2(\mathrm{k}=2)$. Nilai du yang diperoleh dari tabel tersebut adalah 1,62308 .

Pengambilan keputusan pengujian autokorelasi yang menunjukkan apakah model regresi mengalami masalah autokorelasi atau tidak digunakan satu rumusan dalam mengambil keputusan autokorelasi yaitu $\mathrm{du}<\mathrm{dw}<4$-du. Nilai $\mathrm{dw}$ pada hasil pengujian ini adalah sebesar 1,665, jika dimasukkan ke dalam rumusan, maka hasilnya 1,62308 < 1,665 < 4$1,62308=1,62308<1,665<2,37692$ artinya nilai DW 1,665 lebih besar dari batas atas (du) 1,62308 dan kurang dari 2,37692 (4-du). Hal ini menunjukkan bahwa model regresi yang diajukan tidak mengandung gejala autokorelasi positif maupun negatif diantara variabelvariabel independennya, sehingga model regresi layak digunakan.

\subsection{Analisis Regresi Linear Berganda}

Analisis regresi linear berganda digunakan dalam penelitian ini untuk mengetahui pengaruh variabel independen yaitu risiko sistematik dan persistensi laba terhadap variabel dependen yaitu Earnings responce coefficient(ERC). Selain itu, analisis ini digunakan untuk mendapatkan konstanta dankoefesien regresi persamaan regresi linier berganda.

\section{Tabel 4.3}

\section{Hasil Analisis Regresi}

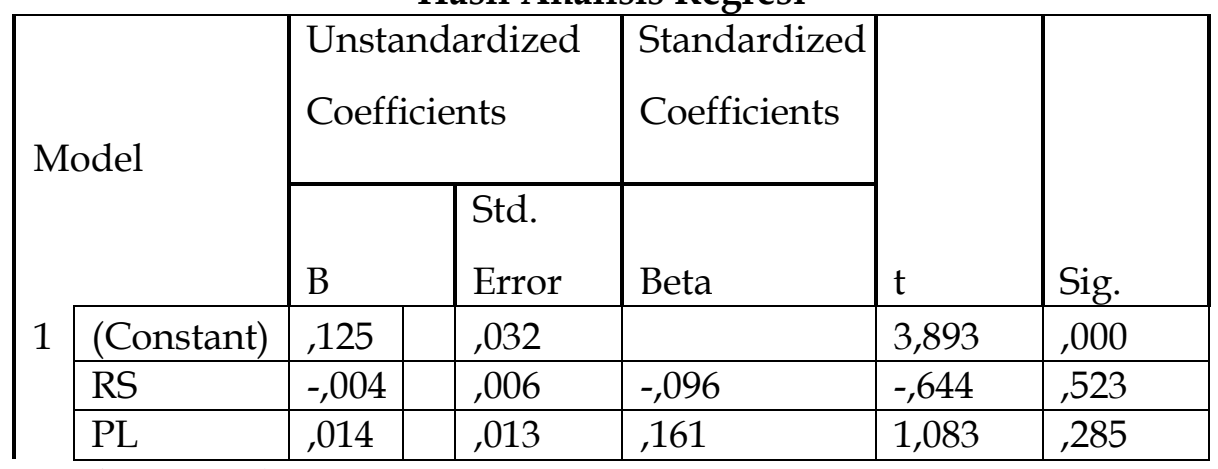

Sumber : Hasil SPSS,2018 


\section{NATIONALLY ACCREDITED JOURNAL - DECREE NO. 21/E/KPT/2018}

Berdasarkan tabel 4.3 di atas dapat disimpulkan bahwa persamaan regresi dalam penelitian ini menjadi :

$$
\mathrm{ERC}=0,125-0,004 \mathrm{RS}+0,014 \mathrm{PL}+\mathrm{e}
$$

\subsection{Pengujian Hipotesis}

\subsubsection{Uji Koefisien Determinasi $\left(R^{2}\right)$}

Nilai koefisien determinasi $\left(\mathrm{R}^{2}\right)$ bertujuan untuk memprediksi seberapa besar kontribusi pengaruh variabel independen terhadap variabel dependen. Berikut hasil pengujian koefisien determinasi model regesi dalam penelitian ini:

Tabal 4.4

Hasil Uji Koefisien Determinasi $\left(\mathbf{R}^{2}\right)$

\begin{tabular}{|c|c|c|c|c|}
\hline Model & $\mathrm{R}$ & R Square & $\begin{array}{l}\text { Adjusted R } \\
\text { Square }\end{array}$ & $\begin{array}{l}\text { Std. Error of } \\
\text { the Estimate }\end{array}$ \\
\hline 1 & $297^{a}$ & ,088 & ,026 & ,11416 \\
\hline
\end{tabular}

Pada tabel 4.4 menunjukkan koefisien determinasi diperoleh nilai $R$ square sebesar 0,026. Hal ini berarti bahwa 2,6\% variabel dependen yaitu ERC dapat dipengaruhi oleh dua variabel independen yaitu risiko sistematik dan persistensi laba, sedangkan sisanya sebesar $97,4 \%$ dapat dipengaruhi faktor-faktor lain di luar variabel penelitian.

\subsubsection{Uji Signifikansi Simultan (Uji Statistik F)}

Uji statistik F pada dasarnya menunjukkan apakah semua variabel independen atau variabel bebas yang dimasukkan dalam model mempunyai pengaruh secara bersama-sama terhadap variabel dependen (Ghozali, 2005:84).

Tabel 4.5 Hasil Uji Statistik F

\begin{tabular}{|l|l|l|l|l|l|l|}
\hline \multicolumn{2}{|l|}{ Model } & $\begin{array}{l}\text { Sum of } \\
\text { Squares }\end{array}$ & Df & $\begin{array}{l}\text { Mean } \\
\text { Square }\end{array}$ & F & Sig. \\
\hline \multirow{2}{*}{1} & Regression &, 055 & 3 &, 018 & 1,419 &, $250^{\mathrm{b}}$ \\
\cline { 2 - 7 } & Residual &, 573 & 44 &, 013 & & \\
\cline { 2 - 7 } & Total &, 629 & 47 & & & \\
\hline
\end{tabular}

a. Dependent Variable: ERC

b. Predictors: (Constant), PL, RS,

Berdasarkan uji ANOVA atau F test diperoleh hasil nilai F hitung sebesar 01,419 dan lebih kecil dari 3. Dan karena probabilitas atau taraf signifikansi 0,250 atau lebih besar dari $\alpha=$ $5 \%$ maka dapat diketahui bahwa variabel independen dengan ukuran risiko sistematik dan persistensi laba secara simultan tidak mempunyai pengaruh terhadap earning respons coefficient 


\subsubsection{Uji Signifikansi Parameter Individual (Uji Statistik $t$ )}

Uji statistik $\mathrm{t}$ menunjukkan seberapa jauh pengaruh satu variabel independen secara individual dalam menerangkan variasi variabel dependen (Ghozali, 2005:84). Pengambilan keputusan dari hasil pengujian ini dilihat dari nilai signifikansi yang dihasilkan dari masing-masing variabel independen.

Tabel 4.6

Hasil Uji ststistik $t$

\begin{tabular}{|l|l|l|l|l|l|l|}
\hline \multicolumn{2}{|c|}{ Model } & \multicolumn{2}{|l|}{\begin{tabular}{l} 
Unstandardized \\
Coefficients \\
\hline
\end{tabular}} & $\begin{array}{l}\text { Standardized } \\
\text { Coefficients }\end{array}$ & & \\
\hline & & & Std. & & & \\
\hline 1 & (Constant) &, 046 &, 045 & & T & Sig. \\
\hline & RS &,- 015 &, 009 &,- 244 & 1,015 &, 316 \\
\hline & PL &, 018 &, 018 &, 143 & $-1,649$ &, 106 \\
\hline
\end{tabular}

a. Dependent Variable: ERC

Berdasarkan tabel 4.6 dapat diketahui bahwa besarnya probabiltas (sig) RS adalah sebesar 0,106. Karena probabilitas lebih besar daripada taraf uji yang digunakan dalam penelitian atau Sig. > a atau 0,106 > 0,05 maka Ho diterima. Dengan demikian dapat disimpulkan bahwa risiko sistematik tidak berpengaruh terhadap earnings response coefficient (ERC) pada perusahaan manufaktur yang terdaftar di Bursa Efek Indonesia pada tahun 2015.

Berdasarkan tabel 4.10 dapat diketahui bahwa besarnya probabiltas (sig) PL adalah sebesar 0,338. Karena probabilitas lebih besar daripada taraf uji yang digunakan dalam penelitian atau Sig. > a atau 0,338 > 0,05 maka Ho diterima. Dengan demikian dapat disimpulkan bahwa persistensi laba tidak berpengaruh terhadap earnings response coefficient (ERC) pada perusahaan manufaktur yang terdaftar di Bursa Efek Indonesia pada tahun 2015.

\subsection{Interpretasi Hasil penelitian}

4.5.1. Pengaruh Risiko Sistematik terhadap Earnings Response Coefficient (ERC)

Berdasarkan hasil analisis statistik dalam penelitian ini ditemukan bahwa risiko sistematik tidak memiliki pengaruh yang signifikan terhadap earningsresponse coefficient (ERC) pada perusahaan manufaktur yang terdaftar di BursaEfek Indonesia pada tahun 2015. Ada beberapa alasan risiko sistematik tidak signifikan berpengaruh terhadap earnings response coefficient (ERC), yang pertama karena risiko sistematik merupakan risiko yang tidak dapat dihilangkan dengan melakukan diversifikasi karena risiko sistematik ini merupakan risiko yang dipengaruhi oleh faktor-faktor makro seperti inflasi, kebijakan pemerintah dan kenaikan suku bunga yang dapat mempengaruhi pasar secara keseluruhan. Kedua, karena perusahaan manufaktur yang ada di Indonesia merupakan perusahaan defensif.

Penelitian ini sejalan dengan penelitian yang dilakukan oleh Hapsari (2014) Amelia (2013) Feby (2015) Dewi dan Sofianty (2016) dan Husiano (2014) yang menyatakan bahwa risiko sistematis tidak berpengaruh terhdap earning response coefficient, namun peneitian ini 
tidak sejalan dengan penelitian delvira dan Nelvirita (2013) yang menemukan bahwa resiko sistematik berpengaruh terhadap earning response coefficient.

\subsubsection{Pengaruh Persistensi Laba terhadap Earnings Response Coefficient(ERC)}

Hasil penelitian ini menunjukkan bahwa persistensi laba tidak berpengaruh terhadap earnings response coefficient (ERC) pada perusahaan manufaktur yang terdaftar di Bursa Efek Indonesia pada tahun 2015. Hal ini berbeda dengan teori yang ada yang menyatakan bahwa persistensi laba memiliki pengaruh positif terhadap earnings response coefficient (ERC). Persistensi laba mencerminkan kualitas laba perusahaan yang menunjukkan bahwa perusahaan mampu mempertahankan laba dari waktu ke waktu. Adanya komponenkomponen transitory dalam laba menyebabkan laba kurang dapat mengukur earnings response coefficient (ERC). Banyaknya komponen transitory hanya berpengaruh terhadap laba saat ini akan tetapi tidak memengaruhi laba di masa datang.

Komponen transitory sifatnya tidak berulang, artinya item transitory merupakan aktifitas yang tidak biasa dilakukan dan tidak selalu terulang dimasa depan. Komponen transitory ini menyebabkan kurang relavannya laba digunakan untuk memprediksi kebijakan di masa datang. Hal ini menunjukkan bahwa investor tidak merespon terhadap perubahan laba meskipun perusahaan telah menunjukkan persistensi laba yang positif untuk masa datang. Hal ini menunjukkan bahwa dalam menentukan investasinya investor tidak hanya menilai berdasarkan informasi laba, akan tetapi investor juga menilai informasi lain yang mungkin berpengaruh terhadap investasinya. Kesimpulan dari hasil penelitian di atas menunjukkan bahwa persistensi laba tidak selalu dapat dijadikan patokan dalam penentuan kebijakan investasi di masa depan.

Hasil penelitian ini sesuai dengan penelitian yang dilakukan oleh Romasari (2013) dan Imroatussholihah (2013) Husiano (2014). Penelitian ini tidak sejalan dengan penilitian yang dilakukan Delvira dan Nelvirita (2013) Hapsari (2014) yang menemukan pengaruh signifikan persistensi laba terhadap earnings response coefficient (ERC).

\section{PENUTUP}

\subsection{Kesimpulan}

Berdasarkan hasil analisis data, pengujian hipotesis dan pembahasan maka dapat diambil kesimpulan sebagai berikut: (1) Risiko sistematik tidak berpengaruh terhadap earnings response coefficient pada perusahaan manufaktur yang terdaftar di bursa efek Indonesia. (2) Persistensi laba tidak berpengaruh terhadap earnings response coefficient pada perusahaan manufaktur yang terdaftar di bursa efek Indonesia tahun 2015.

\subsection{Keterbatasan dan Saran Penelitian}

1. Penelitian ini hanya menggunakan dua variabel yaitu risiko sistematik dan persistensi laba. Untuk penelitian selanjutnya agar menambahkan variabel independen lain yang terkait dengan earnings response coefficient.

2. Tahun pengamatan penelitian yang masih terlalu singkat yaitu hanya tahun 2015 . Untuk penilitian selajutnya agar memperpanjang periode pengamatan. 


\section{DAFTAR PUSTAKA}

Ahmadillah,Haris. (2013) Pengaruh leverage, risiko sistematis dan kualitas auditortterhadap relevansi nilai laba akuntansi. Jurnal Akuntansi, 1(3). Hal: 1-26

Amelia, Novi. (2013). Pengaruh Risiko Sistematis Dan Kesempatan BertumbuhTerhadap Kualitas Laba Pada Perusahaan Manufaktur Yang Terdaftar Di Bursa Efek Indonesia. Skripsi Fakultas Ekonomi Universitas NegeriPadang.

Ariningtyas, Saphira Evani. 2013. Analisis Faktor-Faktor yang Mempengaruhi Pengungkapan Tanggung Jawab Sosial (CSR Disclosure) Perusahaan serta Pengaruhnya terhadap Respon Pasar atas Laba Perusahaan (Earnings Response Coefficient). Jurnal. Fakultas Ekonomi dan Bisnis Universitas Brawijaya.

Brigham, Eugene F dan Joel F Houston. 2001. Manajemen Keuangan. Jakarta:Erlangga.

Diantimala, Yossi (2008). "Pengaruh Akuntansi Konservatif, Ukuran Perusahaan,dan Default Risk terhadap Koefisien Respon Laba (ERC)".Jurnal kuntansi dan Keuangan Indonesia.Vol 1, No.1 : 103-104.

Delvira, Maisil dan Nelvirita. (2013) Pengaruh risiko sistematik, leverage, dan tpersistensi laba terhadap earnings response coefficient. Jurnal WahanaRiset t Akuntansi,Vol. 1, No. 1 April 2013

Deri, Eka Putri. 2010. Faktor-Faktor Yang Mempengaruhi Koefisien Respon LabaPada Perusahaan Manufaktur Yang Terdaftar Di Bei. Skripsi. UniversitasPembangunan Nasional "Veteran".

Etty, Murwaningsari. 2008. Beberapa Faktor yang Mempengaruhi EarningResponse Coefficient. Artikel Keuangan

Feby, Dewi Yanti. (2015). Pengaruh Konservatisme Akuntansi, Risiko Sistematik,Dan Ketepatwaktuan Informasi Terhadap Keresponan Laba Pada Perusahaan Manufaktur Yang Terdaftar Di BEI tahun 2009-2013. Skripsi Fakultas Ekonomi Universitas Negeri Padang.

Fitri, Laila. (2013). Fengaruh Ukuran Perusahaan, Kesempatan Bertumbuh, DanProfitabilitas Terhadap Earnings Response Coefficient. Jurnal Akuntansi, 1(3).

Gogo, Takuanara Lalu. 2015. Analisis Konservatisme Akuntansi, CorporateSocial Responsibility, Profitabilitas terhadap Earning Response Coefficient (Studi Empiris pada Perusahaan Manufaktur Sektor Consumer Goods Industry yang Listing di Bursa Efek Indonesia Tahun 2010-2014. Skripsi. Universitas Islam Negeri Syarif Hidayatullah Jakarta.

Ghozali, Imam. 2005. Aplikasi Analisis Multivariat dengan ProgramSPSS.Semarang : Universitas Diponegoro.

Harahap, S. S 2004. Analisis Kritis Atas Laporan Keuangan. Jakarta: PT Raja Grafindo.

Harahap, Sofyan Syafri. 2009. "Analisis Kritis Laporan Keuangan".Jakarta : PT.Raja Grafindo Persada.

Halim, Abdul. 2005. Analisis Investasi Edisi Kedua. Jakarta : Salemba Empat.

Imroatussolihah, Eli. 2013. Pengaruh Resiko, Leverage, Peluang Pertumbuhan,Persistensi Laba, dan Kualitas Tanggung Jawab Sosial Perusahaan Terhadap Earnings Response Coefficient pada Perusahaan High Profile.Jurnal Ilmu Manajemen. Vol. 1, No. 1.

Jang, Lesia; Sugiarto, Bambang; Siagian, Dergibson. 2007. Faktor-faktor yang Mempengaruhi Kualitas Laba pada Perusahaan Manufaktur di BEJ. Akuntabilitas, 6(2): h:142-149.

Jogiyanto. 2010. Teori Portofolio dan Analisis Investasi. Edisi Ketujuh.Yogyakarta: BPFE UGM. Kurnia, Ivan dan Sufiyati. 2015. Pengaruh Ukuran Perusahaan, Leverage, RisikoSistematik, dan Investment Opportunity Set terhadap Earnings Response Coefficient pada Perusahaan

jmm.unram.ac.id 
Manufaktur yang Terdaftar di Bursa Efek Indonesia pada Tahun 2012-2014. Jurnal Ekonomi. Vol. 20 No. 03halaman 463- 478.

Lukman, Ihsanul. 2014. Pengaruh Ukuran Perusahaan, Kesempatan bertumbuh, dan Leverage terhadap Keresponan Laba ( Studi Empiris pada Perusahaan roperti dan Real Estate yang Terdaftar di BEI tahun 2009-2012). Skripsi Fakultas Ekonomi Universitas Negeri Padang.

Mulyani, Sri ,Nur Fadjrih Asyik dan Andayani. (2007). Faktor-faktor YangMempengaruhi Earnings Response Coefficient Pada Perusahaan Yang Terdaftar di Bursa Efek jakarta. JAAI volume 11 no. 1, juni 2007: 35-45

Margaretta Jatti Palupi. 2006. “AnalisiS Faktor Faktor Yang MempengaruhiKoefisien Respon Laba Bukti Empiris pada Bursa Efek Jakarta". JurnalEKUBANK, Vol 3

Mulyani, Sri, Nur Fadjarih Asyik dan Andayani. 2007.Faktor-Faktor yang MempengaruhiEarning Response Coefficient pada PerusahaanyangTerdaftar di Bursa Efek Jakarta. JAAI. Vol. 11, No. 1, Juli 2015.

Noviyanti Tiolemba dan Erni Ekawati, 2008. “Analisis faktor-faktor yangmempengaruhi koefisien respon laba pada perusahaan manufaktur yang terdapat di BEJ. Jurnal riset akuntansi \& keuangan. Vol. 4 No. 2 Agustus 2008. Hal: 100-115.

Nicky, Poetri Perdani. 2009. Analisis Faktor-faktor yang Mempengaruhi Koefisien Respon Laba. Skripsi. STIE Bank BPD Jateng.

Pamungkas, Fajar Bayu.2014. Pengaruh Ukuran KAP, Ukuran Perusahaan, Profitabilitas, dan Leverage terhadap Koefisien Respon Laba (Studi Empiris pada Perusahaan Manufaktur yang Terdaftar di Bursa Efek Indonesia Tahun 2010-2012). Naskah Publikasi. Universitas Muhammadiyah Surakarta

Paramita, Ratna Wijayanti Diniar. 2012. Pengaruh Firm Size Terhadap EarningResponse Coefficient dengan Voluntary Disclousure sebagai VariabelIntervening. Jurnal WIGA. Vol. 2, No. 1.

Rizky Indra Pradita. 2009. Pengaruh Alokasi Pajak Antar Periode,Persistensilaba Akuntansi, Pertumbuhan Laba Akuntansi Struktur Modal, Besaran Perusahaan Terhadap Earnings Response Coefficient Pada Perusahaan Manufaktur Yang Go Public Di BEI. Skripsi MahasiswaSekolah Tinggi Ilmu Ekonomi Perbanas Surabaya.

Rofika. 2013. Pengaruh Risiko Perusahaan dan Ukuran Perusahaan terhadapEarnings Response Coefficient. Jurnal Pendidikan Ekonomi dan Bisnis Vol 5 no. 2 Juli: 93 -100. Universitas Riau.

Sri Ambarwati. 2008. Earnings Response Coefficient. Akuntabilitas. Vol 7 (2).Maret: 128-134.

Santoso, Gunawan. 2015. Determinan Koefisien Respon Laba. Parsimonia. Vol.No. 2.

Syarifulloh, Rahmat. 2015. Analisis peran struktur modal Dan risiko sistematikdalam memediasi Pengaruh peluang bertumbuh Terhadap koefisien respon laba(Studi Empiris pada Perusahaan Sektor Industri Barang Konsumsi di Bursa Efek Indonesia Tahun 2012-2014). Skripsi FakultasEkonomi Universitas Negeri Semarang

Sugiyono. 2013. Metode Penelitian Kuantitatif, Kualitatif dan RED. Bandung:Alfabeta.

Sri, Mulyani dan Nur Fadrijih. 2007. "Faktor-Faktor Yang MempengaruhiEarnings Response Coefficient Pada Perusahaan Yang Terdaftar Di Bej".JAAI Volume 11 No.1, hal 35-45.

Suaryana. 2008. Pengaruh Komite Audit Terhadap Koefisien Respon Laba. Tesis, Universitas Gajah Mada. Yogyakarta.

Tandelilin, Eduardus.2010.Portofolio dan Investasi (Teori danAplikasi).Yogyakarta: Kanisius.

Wulandari,Kadek Trisna dan I Gede Ary Wirajaya. 2014. Pengaruh Pengungkapan Corporate Social Responsibility terhadap Earnings Response Coefficient. E-Jurnal Akuntansi Universitas Udayana. 
Wulansari,Yenny. (2013) Pengaruh investment opportunity set, likuiditas, danrtleverage terhadap kualitas laba pada perusahaan manufaktur yang terdaftar di BEI. Jurnal Akuntansi. 1(2). www.idx.co.id. (Diakses tanggal 10 April 2017)

www.sahamoke.com(Diakses 2 Maret 2017)

www.yahoofinance.com (Diakses 16 April 2017) 